\title{
Programmed Cell Death Protein 1
}

National Cancer Institute

\section{Source}

National Cancer Institute. Programmed Cell Death Protein 1. NCI Thesaurus. Code C94697.

Programmed cell death protein 1 ( $288 \mathrm{aa}, \sim 32 \mathrm{kDa}$ ) is encoded by the human PDCD1 gene. This protein is involved in the regulation of apoptosis. 